\title{
THE URANIUM-NITROGEN-CARBON SYSTEM
}




\section{LEGAL NOTICE}

This report was prepared as an account of Government sponsored work. Neither the United States, nor the Commission, nor any person acting on behalf of the Commission:

A. Makes any warranty or representation, express or implied, with respect to the accuracy, completeness, or usefulness of the information contained in this report, or that the use of any information, apparatus, method, or process disclosed in this report may not infringe privately owned rights; or

B. Assumes any liabilities with respect to the use of, or for damages resulting from the use of any information, apparatus, method, or process disclosed in this report.

As used in the above, "person acting on behalf of the Commission" includes any employee or contractor of the Commission to the extent that such employee or controctor prepares, handles or distributes, or provides access to, any information pursuant to his employment or contract with the Commission.

Printed in USA

Price 75 cents

Available from the

Office of Technical Services

U. S. Department of Commerce

Wa shington 25, D. C. 


\section{DISCLAIMER}

This report was prepared as an account of work sponsored by an agency of the United States Government. Neither the United States Government nor any agency Thereof, nor any of their employees, makes any warranty, express or implied, or assumes any legal liability or responsibility for the accuracy, completeness, or usefulness of any information, apparatus, product, or process disclosed, or represents that its use would not infringe privately owned rights. Reference herein to any specific commercial product, process, or service by trade name, trademark, manufacturer, or otherwise does not necessarily constitute or imply its endorsement, recommendation, or favoring by the United States Government or any agency thereof. The views and opinions of authors expressed herein do not necessarily state or reflect those of the United States Government or any agency thereof. 


\section{DISCLAIMER}

Portions of this document may be illegible in electronic image products. Images are produced from the best available original document. 
Report No. BMI-1272

UC-25 Metallurgy and Ceramics

(TID-4500, 13th Ed., Rev.)

Contract No. W-7405-eng-92

THE URANIUM-NITROGEN-CARBON SYSTEM

by

Alfred E. Austin

Arnold F. Gerds

June 23,1958

BATTELLE MEMORIAL INSTITUTE

505 King Avenue

Columbus 1, Ohio 
- 
ABSTRACT

INTRODUCTION . . . . . . . . . . . . . . . . . . . . . . . . . . . . 1

EXPERIMENTAL WORK . . . . . . . . . . . . . . . . . . . . 1

Methods . . . . . . . . . . . . . . . . . . . . . . 1

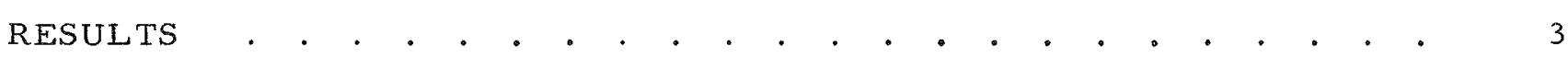

Solid-Solid Reactions . . . . . . . . . . . . . . . . . . 3

Solid-Gas Reactions . . . . . . . . . . . . . . . . . . . . . . 8

Formation of $\mathrm{U}_{2} \mathrm{C}_{3}$.

DISCUSSION AND CONCLUSIONS . . . . . . . . . . . . . . . . . . . . 17

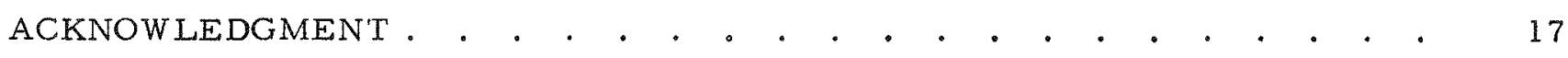

REFERENCES • . . . . . . . . . . . . . . . . . . . . . 18 


\title{
THE URANIUM-NITROGEN-CARBON SYSTEM
}

\author{
Alfred E. Austin and Arnold F. Gerds
}

\begin{abstract}
The ternary system uranium-nitragen-carbon has been studied at $1800 \mathrm{C}$ under vacuum and under a 1-atm nitrogen pressure. There is complete solid solubility between $U N$ and $U C$, and essentially no solid solubility of nitrogen in $U C_{2}$ or $U_{2} C_{3}$ or of carbon in $U_{2} N_{3}$. At $1800 C$ the two-phase field, $U(C, N)$ and $U C_{2}$, and the three-phase field, $U(C, N), U C_{2}$, and $C$, exist in vacuum or argon. At $I$ atm of nitrogen, the uranium nitrides are more stable than the uranium carbides up to $1800 \mathrm{C}$, but at $2000 \mathrm{C}$, the uranium carbides $U C_{2}+U(C, N)$ become more stable. At I atm of nitrogen, $U_{2} N_{3}$ is the stable phase up to $1550 \mathrm{C}$, and $U(N, C)$ solid solution is stable at $1800 \mathrm{C}$.
\end{abstract}

\section{INTRODUCTION}

Uranium carbides and uranium mononitride are stable in inert atmospheres to high temperatures. The structures ${ }^{(1)}$ of UC and UN are isomorphous and the hightemperature structure of $\mathrm{UC}_{2}(2)$ is isomorphous with $\mathrm{UN}_{2}{ }^{(1)}$. Therefore, solid solution between the carbides and nitrides seemed likely. It also appeared possible that mixed carbide-nitride phases may be formed. The composition of solid solutions and the stability of the various phases would be dependent upon nitrogen pressure as are the higher

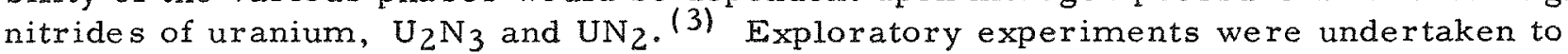
study these factors. Solid-solid reactions between phases of the binary systems, as well as solid-gas reactions between carbide and nitrogen, were used for the study.

\section{EXPERIMENTAL WORK}

Methods

The uranium carbides, nominally $\mathrm{UC}, \mathrm{U}_{2} \mathrm{C}_{3}$, and $\mathrm{UC}_{2}$, were made by arc melting biscuit uranium and carbon under helium. The $\mathrm{U}_{2} \mathrm{C}_{3}$ ingot was heat treated at $1700 \mathrm{C}$ for $4 \mathrm{hr}$ to form the sesquicarbide phase. The carbides were crushed to minus $200 \mathrm{mesh}$ under argon. Powdered uranium nitride, nominally $\mathrm{U}_{2} \mathrm{~N}_{3}$, was prepared by nitriding small pieces of uranium metal at $850 \mathrm{C}$ with prepurified nitrogen at $1 \mathrm{~atm}$. The nitrogen was dried before reaction by passing through a Dry Ice-acetone trap. The uranium was cleaned by pickling in nitric acid before reaction. The mononitride was made from the sesquinitride by heating to $1300 \mathrm{C}$ in vacuum.

The lots of carbides and nitrides were kept sealed under dry argon. Table 1 gives the chemical analyses and cell constants for the se materials.

Mixtures to be employed for solid-solid reactions were prepared by weighing and mixing in a dry argon atmosphere. The mixtures were compacted by moistening with a

(1) References at end. 
solution of $2 \mathrm{w} / \mathrm{o}$ paraffin in $\mathrm{cp}$ benzene (using about $1 \mathrm{~cm}^{3}$ of solution to $10 \mathrm{~g}$ of powders), packing into a 1/8-in. -ID rubber tube, and hydrostatically pressing at $100,000 \mathrm{psi}$. The compacts were removed from the rubber tubing under argon and kept in sealed vials until used. The compacts were placed on powders of the same composition and sintered in a high-frequency induction-heating furnace. The solid-solid reactions were carried out generally by heating at $1800 \mathrm{C}$ in argon and holding for $2 \mathrm{hr}$. The compacts were cooled at about $50 \mathrm{C}$ per min to black heat in argon and then cooled to room temperature at the cooling rate of the furnace. Initially, some compacts had been heated in $\mathrm{BeO}$ crucibles. However, a surface reaction occurred to form $\mathrm{UO}_{2}$ and $\mathrm{Be}_{3} \mathrm{~N}_{2}$.

TABLE 1. CHEMICAL ANALYSES AND CELL CONST ANTS OF URANIUM CARBIDES AND NITRIDES

\begin{tabular}{|c|c|c|c|c|c|}
\hline \multirow[b]{2}{*}{ Material } & \multicolumn{4}{|c|}{ Analysis, w/o } & \multirow[b]{2}{*}{ Phases and Cell Constants, A } \\
\hline & $\mathrm{U}$ & C & $\mathrm{N}$ & $\mathrm{O}$ & \\
\hline UC & 95.3 & 4.64 & 0.04 & - & $4.9598 \pm 0.0003$ \\
\hline $\mathrm{UC}_{2}$ & 91.4 & 8.39 & 0.04 & $\cdots$ & $\begin{array}{c}\mathrm{a}_{\mathrm{o}}=3.509 \pm 0.003, \mathrm{c}_{\mathrm{O}}= \\
5.980 \pm 0.005+\mathrm{UC}\end{array}$ \\
\hline UN & 94.8 & 0.01 & 5.35 & $\ldots$ & $4.8897 \pm 0.0003$ \\
\hline $\mathrm{U}_{2} \mathrm{~N}_{3}$ & 91.2 & 0.03 & $7.0(a)$ & 0.1 to 0.5 & $10.659 \pm 0.001$ \\
\hline $\mathrm{U}_{2} \mathrm{C}_{3}$ & 92.5 & 7.51 & 0.008 & -- & $a_{0}=8.0885 \pm 0.0005+U_{2}$ \\
\hline
\end{tabular}

(a) Nitrogen is low and the analysis is questioned; the cell size would indicate about 8.4 w/o nitrogen.

Reaction products were analyzed for uranium, nitrogen, and carbon. Uranium was determined by ignition to $\mathrm{U}_{3} \mathrm{O}_{8}$ simultaneously with a combustion analysis at $800 \mathrm{C}$ for total carbon. Nitrogen analysis was carried out by the Friederich method ${ }^{(4)}$ after comparative tests on uranium nitrides with the conventional Kjeldahl analysis. The Friederich method for specimens of both nitride and carbide is as follows: weigh about $0.2 \mathrm{~g}$, add $25 \mathrm{~cm}^{3} \mathrm{l}: 1 \mathrm{HCl}$ and $1 \mathrm{~cm}^{3}$ fluosilicic acid, cover, and heat until reaction ceases, cool, add $2 \mathrm{~cm}^{3} 30 \mathrm{w} / \mathrm{o}_{2} \mathrm{O}_{2}$, heat until excess peroxide decomposes, transfer to Parnas-Wagner micro-Kjeldahl, make alkaline with $\mathrm{NaOH}$, distill, collect ammonia in dilute boric acid and titrate with standard $\mathrm{HCl}$ using methyl red from cresol green indicator. The amount of free carbon was determined by combustion of the residue after hydrolyzing in $50 \mathrm{~cm}^{3} 1: 1 \mathrm{HCl}$ plus $2 \mathrm{~cm}^{3}$ of $30 \mathrm{w} / \mathrm{o} \mathrm{H}_{2} \mathrm{O}_{2}$, washing with $\mathrm{HCl}$, water, and ethyl ether, and drying at $110 \mathrm{C}$. Oxygen and hydrogen were determined by the vacuumfusion method. Metallographic examination and $\mathrm{X}$-ray diffraction analyses were used to determine the phases present in samples cooled from $1800 \mathrm{C}$.

The cell sizes of the cubic phases and solid solutions were determined by graphical extrapolation of the X-ray diffraction data taken with $\mathrm{FeK}$ radiation in a 114.57-mm Debye camera. The densities of the sintered compacts were determined using a pycnometer.

Reactions in nitrogen at a l-atm pressure were carried out in a high-temperature $\mathrm{X}$-ray camera. Samples consisted of carbide powder, pressed compacts, and solid pieces from arc-melted ingots. Some initial reactions made at $1000 \mathrm{C}$ and a 1 -atm pressure of nitrogen indicated complete reaction of a $20-\mathrm{mil}$ rod of sintered carbide in 
$2 \mathrm{hr}$ to form $\mathrm{U}_{2} \mathrm{~N}_{3}$. Therefore, reactions of powder and compacts at 1000 to $2000 \mathrm{C}$ or higher were carried out for 2 to $3 \mathrm{hr}$.

RESULTS

Solid-Solid Reactions

The reactions between $\mathrm{UC}, \mathrm{UC}_{2}, \mathrm{UN}, \mathrm{U}_{2} \mathrm{~N}_{3}$, and graphite were investigated for mixtures heated to 1800 to $1850 \mathrm{C}$ for $2 \mathrm{hr}$ in dry argon. This temperature was selected since prior work with binary carbides had shown complete reaction in $2 \mathrm{hr}$ at about $1800 \mathrm{C}$. Figure 1 shows the ternary section determined for $1800 \mathrm{C}$. Tables 2 and 3 give compositions and phase analyses. Uranium mononitride, UN, is the only stable nitride in a vacuum or a nitrogen-free atmosphere at this temperature. There is complete solid solubility between UN and UC.

Figure 2 shows a plot of the $U(C, N)$ cell size as a function of the mol fraction of $U C$ in the solid solution. The compositions for the two-phase $U(C, N)+U_{2}$ specimens, $4,9,10,14$, and 15, are shown on the plot. These specimens were each corrected for the presence of carbon or $U_{2}$ by assuming that all of the nitrogen was in the $U(C, N)$ phase. The deviation of the cell size from linearity indicates that carbon and nitrogen are more soluble in $U(C, N)$, in the region of 0.65 to $0.75 \mathrm{~mol}$ fraction $U C$, than expected by additivity between UC and UN.

The cell size, $4.9254 \pm 0.0005 \mathrm{~A}$, for $0.50 \mathrm{~mol}$ fraction UC, was obtained from the core of a reacted compact of equimolar ratio of UC and UN. The cell size of the $\mathrm{UC}_{2} \mathrm{did}^{\mathrm{N}}$ not change for the two- and three-phase specimens, indicating very little if any solid solubility of nitrogen in $\mathrm{UC}_{2}$.

The single-phase specimens, 8, 12, and 26, were analyzed for oxygen impurity with results of $0.14,0.05$, and $0.10 \mathrm{w} / \mathrm{o}$ of oxygen respectively. The se amounts of oxygen are too low compared with the carbon and nitrogen contents to account for the deviation of cell size from linearity for Specimens 8 and 26 in Figure 2. Previously reported work $(5)$ indicated linearity of the cell size for the $U(C, O)$ phase.

Specimens 12A and 25 in the ternary-phase field were fired twice, with crushing to minus 325 mesh and recompaction between firings, to promote complete reaction. The cell size, $4.9417 \mathrm{~A}$, for $\mathrm{U}(\mathrm{C}, \mathrm{N})$ in Specimen 12A lies between the values for the $\mathrm{U}(\mathrm{C}, \mathrm{H})$ phase in Specimens $10\left[\mathrm{U}(\mathrm{C}, \mathrm{N})+\mathrm{UC}_{2}\right]$ and $12[\mathrm{U}(\mathrm{C}, \mathrm{N})+\mathrm{C}]$. The addition of carbon to Specimen 12 in making Specimen $12 \mathrm{~A}$ shifted the composition from the twophase field into the three-phase field. The best estimate for the terminal composition of the U(C,N) for the three-phase field is $0.62 \mathrm{~mol}$ fraction UC, $0.38 \mathrm{~mol}$ fraction UN, with uranium between 50 and 49 a/o.

Density measurements, shown in Table 4, can, in general, be correlated with the phase identifications. The theoretical densities calculated from X-ray diffraction data are as follows: UC, $13.6 \mathrm{~g}$ per $\mathrm{cm}^{3} ; \mathrm{UC}_{2}, 11.68 \mathrm{~g}$ per $\mathrm{cm}^{3} ; \mathrm{UN}, 14.32 \mathrm{~g} \mathrm{per} \mathrm{cm}^{3}$; and $\mathrm{U}_{2} \mathrm{~N}_{3}, 11.24 \mathrm{~g}$ per $\mathrm{cm}^{3}$. An experimental density of $13.06 \mathrm{~g}$ per $\mathrm{cm}^{3}$ was determined for UC. This is lower than the theoretical density, probably because of the presence of some $\mathrm{UC}_{2}$, which has a lower density, in the structure. The U(C,N) solid solution was 


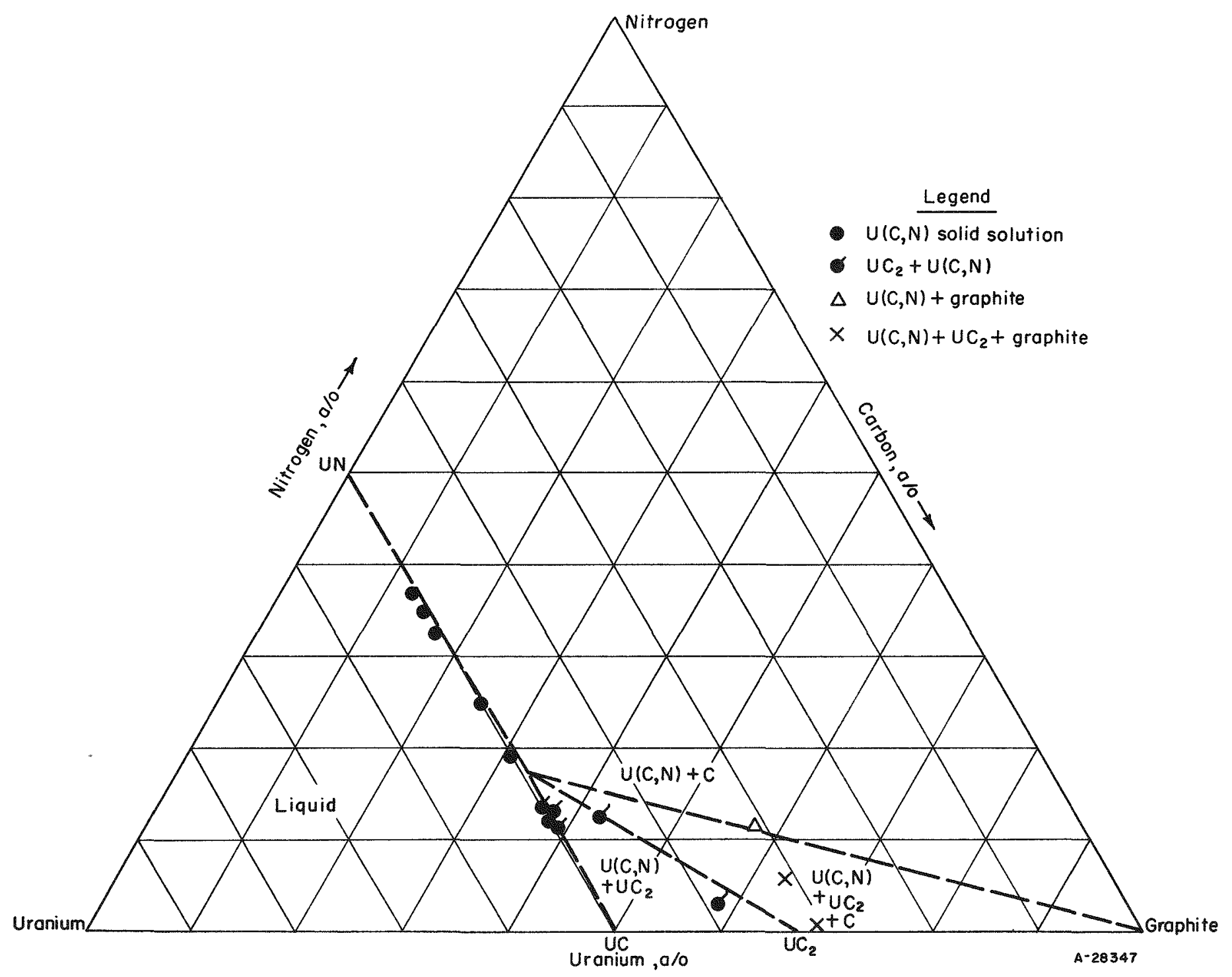

FIGURE 1. TERNARY SECTION OF URANIUM-CARBON-NITROGEN SYSTEM AT 1800 C IN ARGON ATMOSPHERE 
TABLE 2. COMPOSITIONS OF URANIUM-NITROGEN-CARBON SPECIMENS REACTED AT 1800 C IN ARGON

\begin{tabular}{|c|c|c|c|c|c|c|c|c|c|c|}
\hline \multirow[b]{3}{*}{ Specimen } & \multirow[b]{3}{*}{ Reactants } & \multicolumn{9}{|c|}{ Compositions } \\
\hline & & \multicolumn{3}{|c|}{ Initial, a/o } & \multicolumn{3}{|c|}{ Products, $w / 0$} & \multicolumn{3}{|c|}{ Products, a/o } \\
\hline & & $\mathrm{U}$ & $C$ & $\mathrm{~N}$ & $\mathrm{U}$ & $\mathrm{C}$ & $\mathrm{N}$ & $\mathrm{U}$ & C & $\mathrm{N}$ \\
\hline 3 & $\mathrm{UC}+\mathrm{U}_{2} \mathrm{~N}_{3}$ & 43.1 & 20.5 & 34.8 & 94.7 & 1.67 & 3.53 & 51.0 & 16.8 & 32.3 \\
\hline 4 & $\mathrm{U}_{2} \mathrm{~N}_{3}+\mathrm{UC}_{2}$ & 36.9 & 33.2 & 30.0 & 94.9 & 3.70 & 1.52 & 49.0 & 37.8 & 13.3 \\
\hline 8 & $\mathrm{UC}+\mathrm{UN}$ & 51.0 & 34.6 & 13.3 & 94.8 & 2.91 & 2.11 & 50.3 & 30.6 & 19.1 \\
\hline 9 & $\mathrm{UN}+\mathrm{UC}_{2}$ & 41.6 & 37.4 & 21.1 & 94.7 & 3.76 & 1.35 & 49.4 & 38.4 & 11.8 \\
\hline 10 & $\mathrm{UN}+\mathrm{C}$ & 33.4 & 33.2 & 33.4 & 94.1 & 4.44 & 1.55 & 45.2 & 42.3 & 12.6 \\
\hline 11 & $\mathrm{UN}+\mathrm{UC}$ & 50.1 & 15.1 & 35.0 & 94.8 & 1.14 & 3.72 & 51.5 & 12.5 & 35.2 \\
\hline 12 & $U N+C$ & 24.9 & 51.0 & 23.9 & 89.8 & 8.22 & 1.98 & 31.3 & 57.9 & 11.8 \\
\hline 13 & $\mathrm{UC}+\mathrm{U}_{2} \mathrm{~N}_{3}$ & 41.5 & 13.8 & 44.8 & 94.8 & 1.34 & 3.71 & 51.3 & 14.4 & 34.2 \\
\hline 14 & $\mathrm{UC}+\mathrm{U}_{2} \mathrm{~N}_{3}$ & 48.2 & 39.2 & 12.6 & 95.0 & 3.52 & 1.52 & 49.9 & 36.6 & 13.6 \\
\hline 15 & $\mathrm{U}_{2} \mathrm{~N}_{3}+\mathrm{UC}_{2}$ & 35.7 & 55.4 & 8.8 & 92.6 & 7.01 & 0.43 & 38.7 & 58.2 & 3.1 \\
\hline 25 & $\mathrm{UN}+\mathrm{UC}_{2}+\mathrm{C}$ & 27.9 & 66.5 & 5.6 & 89.8 & 10.0 & 0.1 & 31.0 & 68.4 & 0.6 \\
\hline $12 A(a)$ & $\mathrm{UN}+\mathrm{C}^{2}$ & - & $-\infty$ & - & 89.6 & 9.3 & 1.0 & 30.8 & 63.3 & 5.8 \\
\hline 26 & $\mathrm{UN}+\mathrm{UC}$ & 50.8 & 39.5 & 9.8 & 94.9 & 3.62 & 1.40 & 49.9 & 37.6 & 12.5 \\
\hline
\end{tabular}

(a) Specimen $12 \mathrm{~A}$ was Specimen 12 crushed and repressed with slight additional carbon from paraffin binder.

TABLE 3. PHASES FORMED IN URANIUM-NITROGEN-CARBON SPECIMENS AT $1800 \mathrm{C}$ IN ARGON

\begin{tabular}{|c|c|c|c|}
\hline \multirow[b]{2}{*}{ Specimen } & \multicolumn{2}{|c|}{ Phases Identified } & \multirow{2}{*}{$\begin{array}{l}\text { Cubic Solid-Solution } \\
\text { Cell Constant }{ }^{(b)} \text {, A }\end{array}$} \\
\hline & By Metallography(a) & By X-Ray Diffraction & \\
\hline 3 & $\mathrm{U}(\mathrm{N}, \mathrm{C})+$ trace $\mathrm{UO}_{2}$ & $\mathrm{U}(\mathrm{N}, \mathrm{C})$ & $\begin{array}{l}4.9415 \text { for minor phase } \\
4.9068 \text { for major phase }\end{array}$ \\
\hline 4 & $\mathrm{U}(\mathrm{C}, \mathrm{N})+\mathrm{UC}_{2}$ & $U(C, N)+U_{2}$ & 4.9480 \\
\hline 8 & $\mathrm{U}(\mathrm{N}, \mathrm{C})$ & $\mathrm{U}(\mathrm{N}, \mathrm{C})$ & 4.9454 \\
\hline 9 & $U(C, N)+U C_{2}$ & $U(C, N)+U_{2}$ & 4.9487 \\
\hline 10 & $\mathrm{U}(\mathrm{C}, \mathrm{N})+\mathrm{UC}_{2}$ & $U(C, N)+U C_{2}$ & 4.9474 \\
\hline 11 & $\mathrm{U}(\mathrm{N}, \mathrm{C})$ & $\mathrm{U}\left(\mathrm{N}_{\mathrm{\theta}} \mathrm{C}\right)$ & 4.9088 \\
\hline 12 & $\mathrm{U}(\mathrm{C}, \mathrm{N})+\mathrm{C}$ & $U(C, N)+C$ & 4.9393 \\
\hline 13 & $\mathrm{U}(\mathrm{N}, \mathrm{C})+\operatorname{trace} \mathrm{UO}_{2}$ & $\mathrm{U}(\mathrm{N}, \mathrm{C})$ & 4.9096 \\
\hline 14 & $\mathrm{U}(\mathrm{C}, \mathrm{N})+\mathrm{UC}_{2}$ & $\mathrm{U}(\mathrm{C}, \mathrm{N})$ & 4.9495 \\
\hline 15 & $\mathrm{UC}_{2}+\mathrm{U}(\mathrm{C}, \mathrm{N})$ & $\mathrm{UC}_{2}+\mathrm{U}(\mathrm{C}, \mathrm{N})$ & 4.9565 \\
\hline 25 & $U C_{2}+U\left(C_{3} N\right)+C$ & $U C_{2}+U(C, N)+C$ & (c) \\
\hline 26 & $\mathrm{U}(\mathrm{C}, \mathrm{N})$ & $\mathrm{U}(\mathrm{C}, \mathrm{N})$ & 4.9482 \\
\hline $12 \mathrm{~A}$ & $U C_{2}+U(C, N)+C$ & $U C_{2}+U(C, N)+C$ & 4.9417 \\
\hline
\end{tabular}

(a) UC phase stains and UN phase does not. Therefore, $U(C, N)$ denotes a stained solid solution phase and $U(N, C)$ denotes an unstained solid-solution phase. C indicates graphite.

(b) Error in cell constants was $0.0005 \mathrm{~A}$.

(c) Cell constant not determined. 


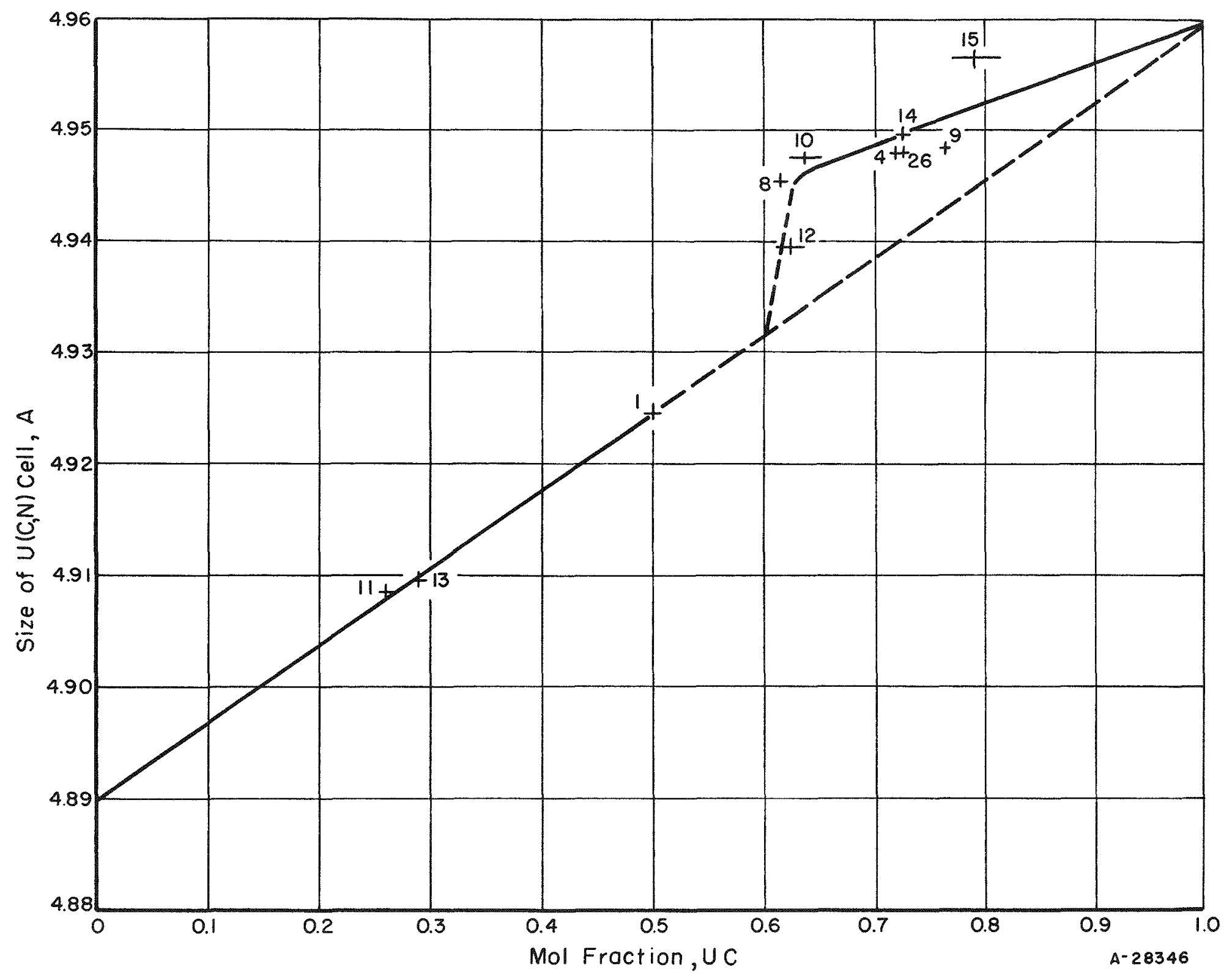

o

FIGURE 2. PLOT OF U(C,N) CELL SIZE VERSUS MOL FRACTION OF UC IN SOLID SOLUTION 
more dense than UC, as might be expected, because the density of UN is higher than that of UC. The presence of graphite in the microsturcture lowers the density appreciably, as can be seen for Specimen 12. UN and the $U(N, C)$ solid solutions have appreciably higher densities than $U C$ and the $U(C, N)$ solid solutions. Thus, qualitatively, there is agreement between the experimental density measurements and the phases present in test samples.

TABLE 4. DENSITY MEASUREMENTS ON URANIUM $-N I T R O G E N \backsim C A R B O N$ SPECIMENS FORMED AT $1800 \mathrm{C}$ IN ARGON

\begin{tabular}{|c|c|c|}
\hline Specimen $^{(a)}$ & $\begin{array}{l}\text { Phases Present } \\
\text { in Specimen }(b)\end{array}$ & $\begin{array}{l}\text { Density }(c) \\
\text { g per } \mathrm{cm}^{3}\end{array}$ \\
\hline$\cdots$ & $\mathrm{UC}$ & 13.06 \\
\hline 26 & $U(C, N)$ & 13.81 \\
\hline 14 & $U(C, N)+U C_{2}$ & 13.52 \\
\hline 10 & $U(C, N)+U C_{2}$ & 13.06 \\
\hline 9 & $U(C, N)+U_{2}$ & 13.81 \\
\hline 12 & $U(C, N)+C$ & 10.43 \\
\hline$-\infty$ & $\mathrm{UC}_{2}$ & 11.38 \\
\hline$-\infty$ & UN & 14.18 \\
\hline 8 & $U(N, C)$ & 13.94 \\
\hline 3 & $U(N, C)$ & 13.65 \\
\hline 11 & $\mathrm{U}(\mathrm{N}, \mathrm{C})$ & 14.54 \\
\hline 13 & $\mathrm{U}(\mathrm{N}, \mathrm{C})$ & 14.03 \\
\hline$-\infty$ & $\mathrm{U}_{2} \mathrm{~N}_{3}$ & 11.26 \\
\hline
\end{tabular}

(a) Specimens as utumbered in Tables 2 and 3.

(b) Phases determined by metallographic methods.

(c) Calculated densities from $X-r a y$ diffraction data are as follows:

\begin{tabular}{lc} 
& G per $\mathrm{Cm}^{3}$ \\
\hline $\mathrm{UC}$ & 13.6 \\
$\mathrm{UC}_{2}$ & 11.68 \\
$\mathrm{UN}$ & 14.32 \\
$\mathrm{U}_{2} \mathrm{~N}_{3}$ & 11.24
\end{tabular}

Figures 3 through 10 show typical microstructures of specimens, reacted at 1800 to $1850 \mathrm{C}$, that were used in the study. All of the photomicrographs are at 500X. The gray material between the particles is mounting resin used to facilitate handling of the specimens. Figure 3 shows a typical field of the $U(N, C)$ solid solution which was formed by reaction at 1750 to $1800 \mathrm{C}$ of equal parts of UC and UN. Lattice-parameter measurements and analytical data indicate the nonstaining matrix to be a nitrogen-rich compound composed of uranium, nitrogen, and carbon, and designated $U(N, C)$ in this report. The small dark-etching particles in the matrix phases are not identified.

Figure 4 shows a typical field in a specimen composed of equal parts of $U_{2} \mathrm{~N}_{3}$ and $\mathrm{UC}_{2}$ reacted in argon for $2 \mathrm{hr}$ at 1750 to $1800 \mathrm{C}$. The major phase stained similar to UC. X-ray diffraction studies and analyses for uranium, nitrogen, and carbon indicated that the stained phase is a carbon-rich solid solution of uranium in the form $U(C, N)$. The few, isolated, light-etching particles in the stained matrix are probably $\mathrm{UC}_{2}$. 
Figure 5 shows the typical microstructure in a specimen produced by reaction of equal parts of $U N$ and $\mathrm{UC}_{2}$ at 1750 to $1800 \mathrm{C}$. The matrix of the stained particles is $U(C, N)$, while the light-etching grain-boundary phase is $U C_{2}$. The several light-etching particles containing the stained bands in the center of the field have a $\mathrm{UC}_{2}$ matrix. The stained bands within the se particles probably are composed of the $U(C, N)$ solid solution precipitated in the $\mathrm{UC}_{2}$ matrix.

Figure 6 shows the structure produced by reaction of 19 parts of UN with 1 part of graphite. The light-etching material in the center of the field appears to contain a $\mathrm{UC}_{2}$ matrix with bands of a dark-etching phase, probably U(C,N). The smaller particles surrounding this material are the stained $U(C, N)$ phase. The small amount of lightetching material associated with the stained particles is $\mathrm{UC}_{2}$.

Figure 7 shows the microstructure produced by reaction of 9 parts of UN with 1 part of graphite. The discrete particles are the U(C,N) solid solution. The small dark inclusions within the particles were not identified. The gray patches between the particles are graphite. These can be distinguished from the smooth gray mounting resin.

Figure 8 shows the microstructure produced by reaction of 5 parts of UC with 1 part of $U_{2} \mathrm{~N}_{3}$. The stained particles are the $U(C, N)$ solid solution. Within the particles, wavy lines of a fine, light-etching Widmanstätten precipitate of $\mathrm{UC}_{2}$ are evident.

Figure 9 shows the microstructure produced by reaction of 5.5 parts of $\mathrm{UC}_{2}$ with 1 part of $\mathrm{U}_{2} \mathrm{~N}_{3}$ at $1800 \mathrm{C}$ for $2 \mathrm{hr}$. The light-etching particles are $\mathrm{UC}_{2}$. The darketching bands in the light-etching particles are $U(C, N)$. This photomicrograph shows that $\mathrm{U}(\mathrm{C}, \mathrm{N})$ can replace $\mathrm{UC}$ in a $\mathrm{UC}_{2}$-rich material without appreciably changing its appearance under the microscope.

Figure 10 shows the microstructure produced by reaction at $1700 \mathrm{C}$ for $2 \mathrm{hr}$ of 16 parts of $\mathrm{UC}_{2}, 4$ parts of $U N$, and 1 part of graphite. The $\mathrm{UC}_{2}$ appears as the lightto-gray etching matrix, depending upon grain orientation. The dark precipitated bands in the particles are $U(C, N)$. The swirly black material between some of the particles is graphite, while the dark-gray material between the particles is the mounting resin.

Solid-Gas Reactions

The reaction of uranium carbides with nitrogen at a 1 -atm pressure was investigated from 1000 to $2000 \mathrm{C}$. Rods of UC, 20 mils in diameter, were heated at $1000 \mathrm{C}$ under 1 atm of dried prepurified nitrogen in a high-temperature X-ray diffraction camera. Within $2 \mathrm{hr}$ the specimen was changed from UC with a lattice parameter of $5.0110 \mathrm{~A}$ to a face-centered-cubic fluorite-type structure with a lattice parameter of $5.36 \mathrm{~A}$. A duplicate run gave the same result. The crushed rod at room temperature had the typical doubled fluorite cell of the $\mathrm{U}_{2} \mathrm{~N}_{3}$ structure(1). Apparently at $1000 \mathrm{C}$ the $\mathrm{U}_{2} \mathrm{~N}_{3}$ structure shifts to the smaller defect fluorite cell. There was complete reaction of the UC with the nitrogen. 


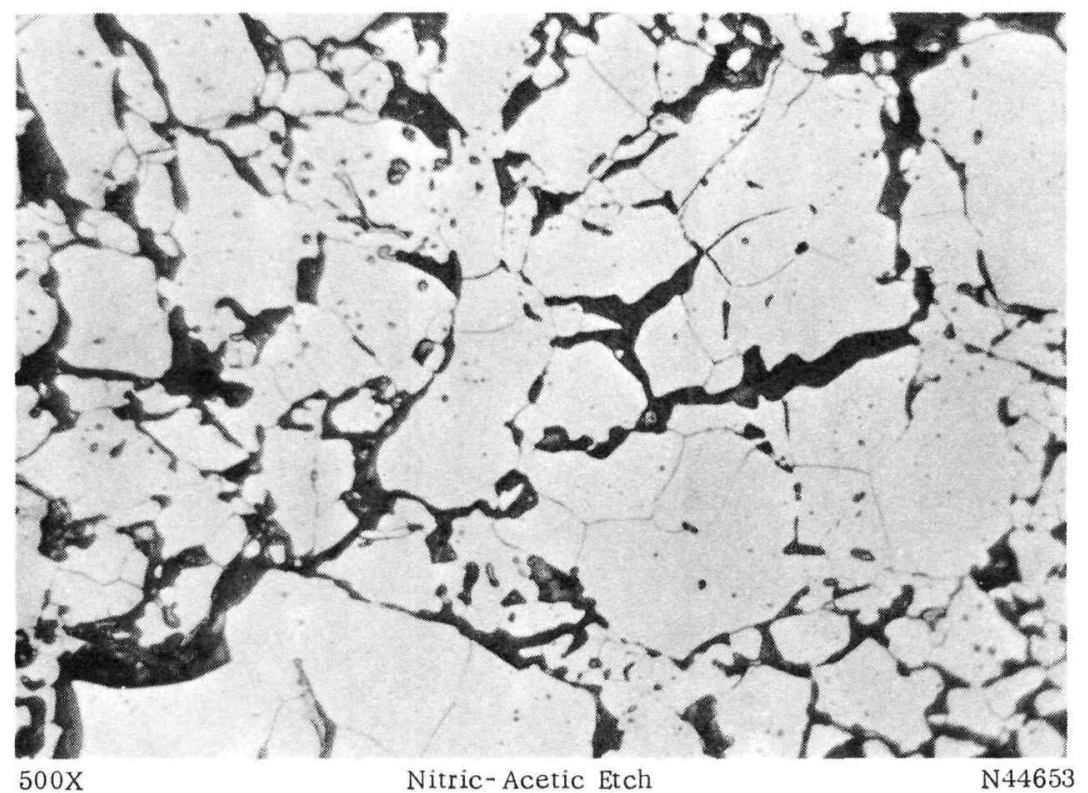

Shows U(N, C) matrix containing a few small particles of a darker etching phase. Dark gray material between particles is mounting resin.

FIGURE 3. SPECIMEN 1, PREPARED WITH EQUAL WEIGHTS OF UN AND UC

Powders mixed, compacted, and argon sintered at 1750 to $1800 \mathrm{C}$ for $2 \mathrm{hr}$ and slowly couled.

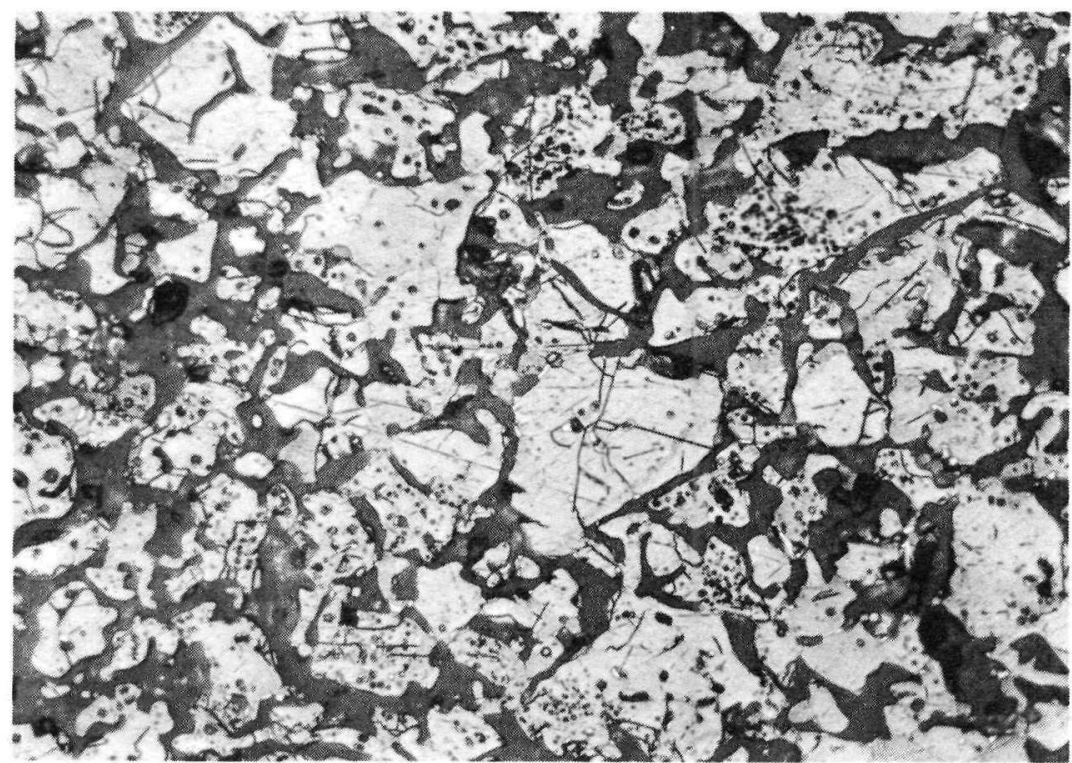

Shows stained $\mathrm{U}(\mathrm{C}, \mathrm{N})$ matrix with occasional unidentified light-etching particles, probably $\mathrm{UC}_{2}$. Dark gray material between particles is mounting resin.

FIGURE 4. SPECIMEN 4, PREPARED WITH EQUAL WEIGHTS OF U $\mathrm{N}_{3}$ AND UC 2

Powders mixed, compacted, and argon sintered at 1750 to $1800 \mathrm{C}$ for $2 \mathrm{hr}$ and slowly cooled. 


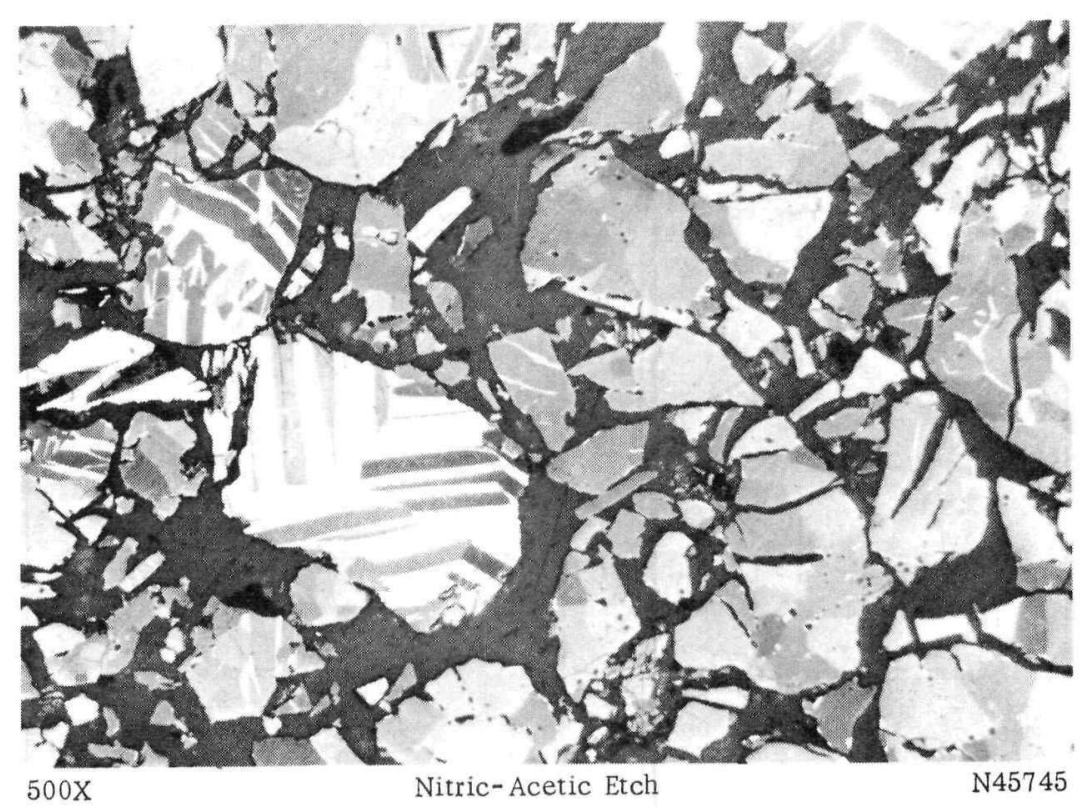

Shows stained $\mathrm{U}(\mathrm{C}, \mathrm{N})$ particles. Light-etching phase in stained particles as well as light-etching banded particles are $\mathrm{UC}_{2}$. Dark material between particles is mounting resin.

FIGURE 5. SPECIMEN 9. PREPARED WITH EQUAL WEIGHTS OF UN AND UC 2 Powders mixed. compacted, and argon sintered at 1750 to $1800 \mathrm{C}$ for 2 hr and slowly cooled.

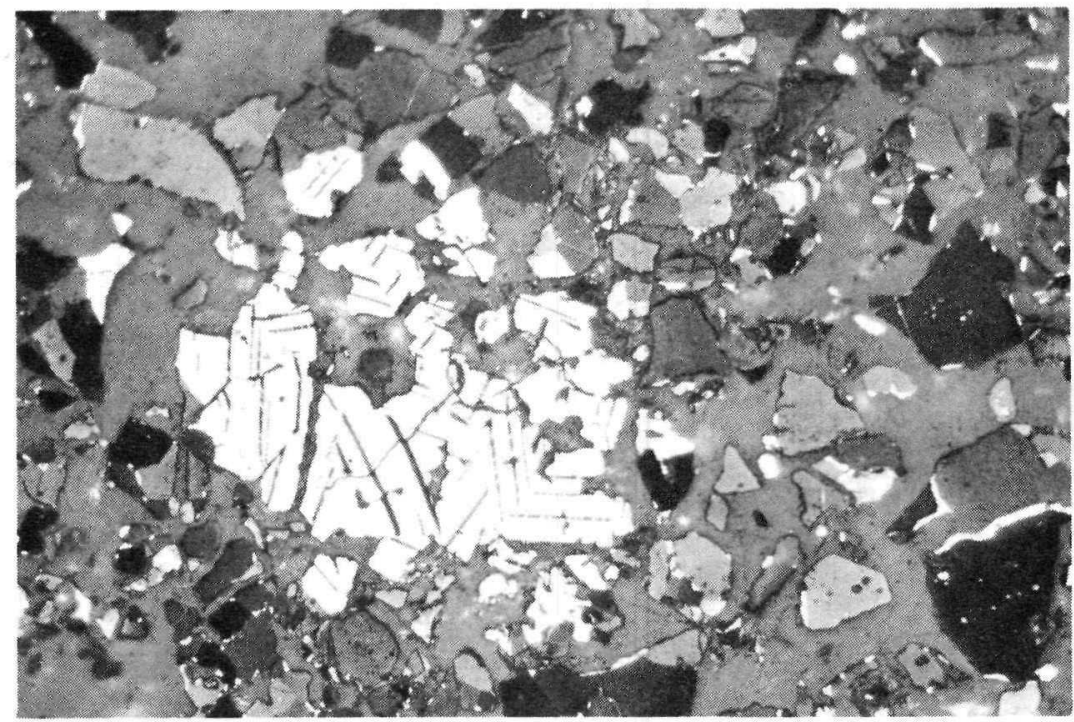

$500 \mathrm{x}$

Nitric-Acetic Etch

N45747

Shows patch of light-etching $\mathrm{UC}_{2}$ in a matrix of stained $\mathrm{U}(\mathrm{C}, \mathrm{N})$. Gray material between particles is mounting resin.

FIGURE 6. SPECIMEN 10, PREPARED WITH 19 PARTS OF UN AND 1 PART OF GRAPHITE

Mixed. compacted, and argon sintered at 1750 to $1800 \mathrm{C}$ for 2 hr and slowly cooled. 


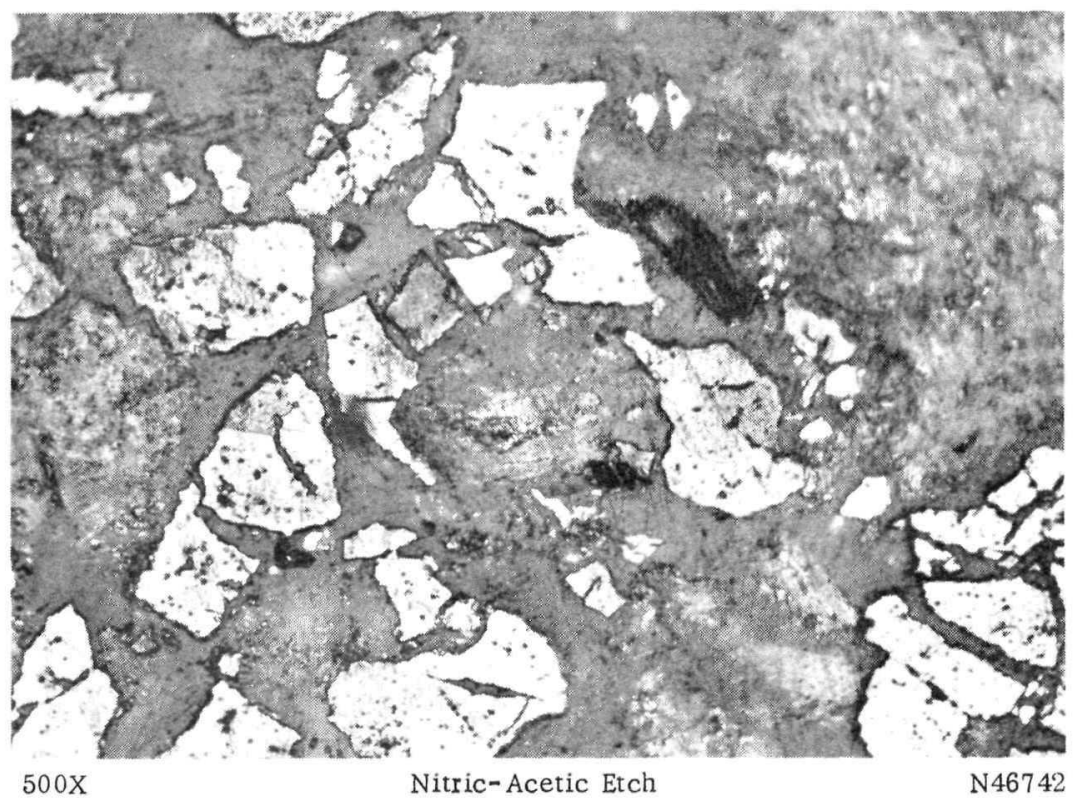

Shows particles of stained U(C, N). Light-gray swirly patches are graphite in a slightly darker gray mounting resin.

FIGURE 7. SPECIMEN 12, PREPARED WITH 9 PARTS OF UN AND 1 PART OF GRAPHITE

Powders mixed, compacted, and sintered in argon at 1750 to $1800 \mathrm{C}$ and slowly cooled.

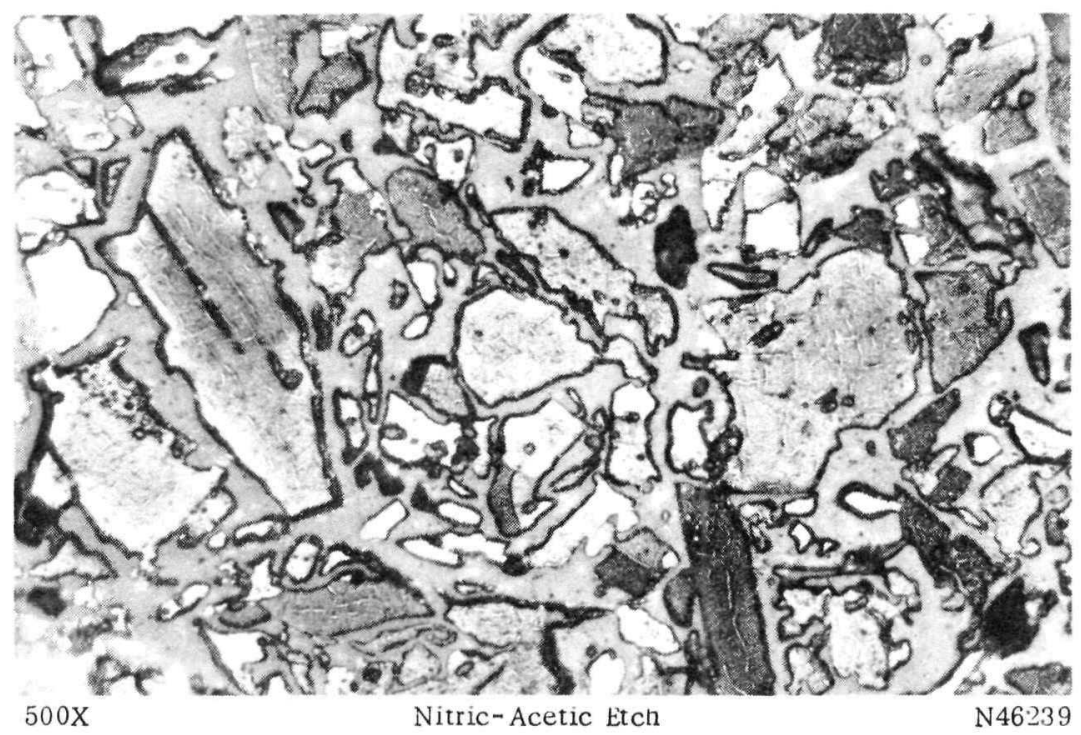

Shows stained U(C,N) particles containing a small amount of lighter etching phase, probably $\mathrm{UC}_{2}$. Gray material between particles is mounting resin.

FIGURE 8. SPECIMEN 14, PREPARED WITH 5 PARTS OF UC AND 1 PART OF $\mathrm{U}_{2} \mathrm{~N}_{3}$

Powder mixed, compacted. and sintered at 1750 to $1800 \mathrm{C}$ in argon and slowly cooled. 


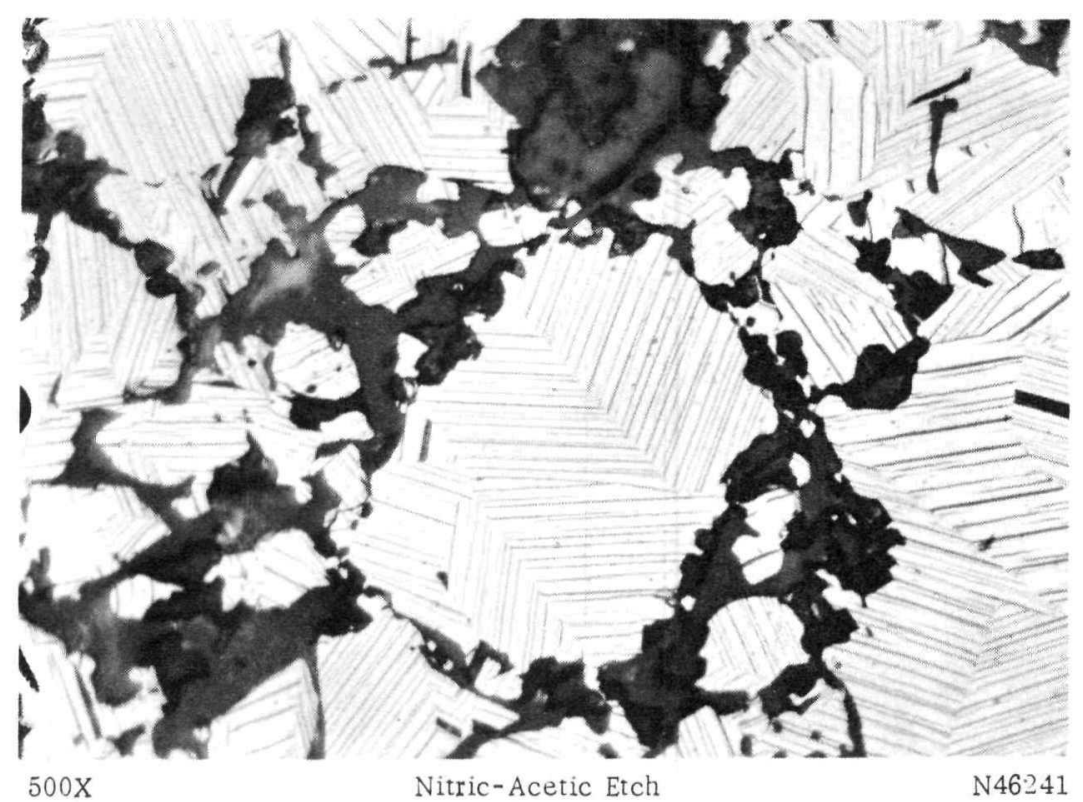

Shows particles typical of $\mathrm{UC}_{2}$. Dark bands within particles are $\mathrm{U}(\mathrm{C}, \mathrm{N})$. Gray material between particles is mounting resin.

FIGURE 9. SPECIMEN 15, PREPARED WITH 5.5 PARTS OF UC 2 AND 1 PART OF $\mathrm{U}_{2} \mathrm{~N}_{3}$

Powder mixed, compacted, and sintered in argon at 1750 to $1800 \mathrm{C}$ for $2 \mathrm{hr}$ and slowly cooled.

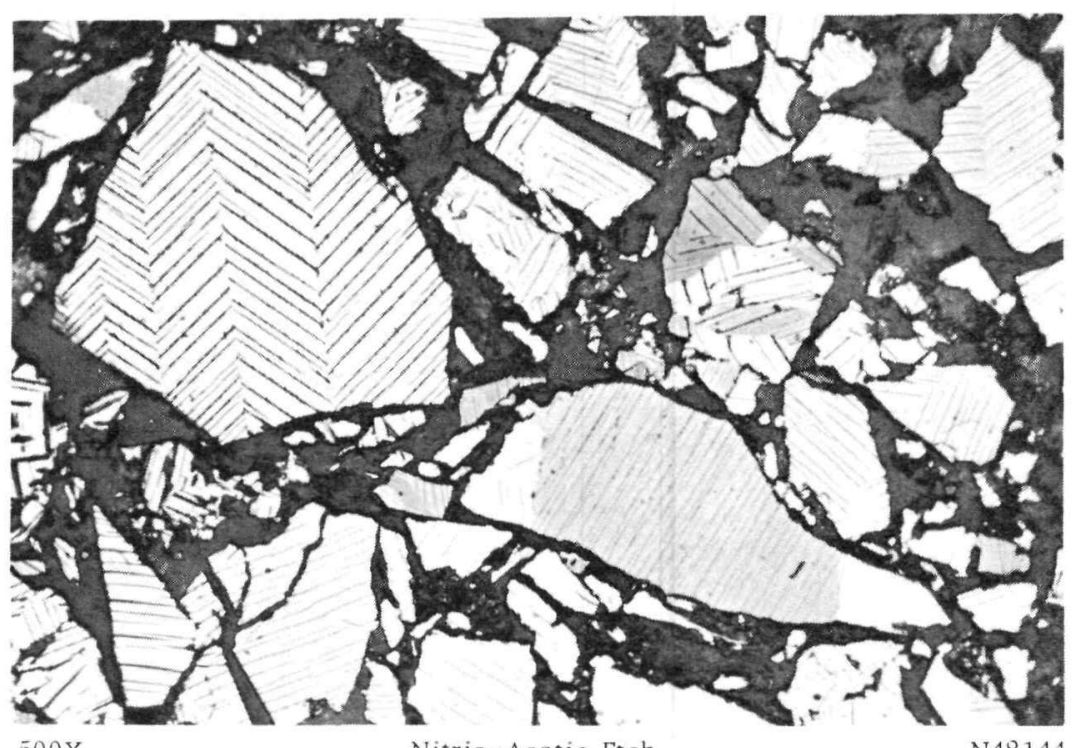

$500 \mathrm{X}$

Nitric-Acetic Etch

N48144

Shows light-etching $\mathrm{UC}_{2}$ particles with dark-etching $\mathrm{U}(\mathrm{C}, \mathrm{N})$ precipitate. Black material adjacent to particles is graphite. Gray material between particles is mounting resin.

FIGURE 10. SPECIMEN 25, PREPARED WITH 4 PARTS OF UN, 16 PARTS OF UC.2, AND 1 PART OF CARBON

Mixed, compacted, and sintered at $1700 \mathrm{C}$ for $2 \mathrm{hr}$ in argon and slowly cooled. Resintered in argon at 1800 to $1850 \mathrm{C}$ for $2 \mathrm{hr}$ and slowly cuoled. 
Further reactions of bulk $\mathrm{UC}$ and $\mathrm{UC}_{2}$ powder with nitrogen were carried out. At 1000,1300 , and $1550 \mathrm{C}$, reactions were performed with the carbide powder in platinum crucibles heated in a Globar-tube furnace for $3 \mathrm{hr}$. At 1800 and $2000 \mathrm{C}$, UC 2 was heated as a compacted powder and also as massive pieces from arc-melted ingots. The samples were placed on $\mathrm{UC}_{2}$ chips in a graphite crucible and heated slowly in dry prepurified nitrogen to temperature. They were heated at temperature for $3 \mathrm{hr}$ and slowly cooled in nitrogen to room temperature. Table 5 gives data on the chemical analyses and phase identifications. The weak graphite diffraction pattern in the $\mathrm{U}_{2} \mathrm{~N}_{3}$ products was masked by the $\mathrm{U}_{2} \mathrm{~N}_{3}$ pattern. Calculation from weight gains for the reactions indicated the product was $\mathrm{UN}_{1.67}$ at $1000 \mathrm{C}$ and $\mathrm{UN}_{1.48}$ at $1300 \mathrm{C}$. The $1000 \mathrm{C}$ value is slightly higher than expected according to vapor-pressure data $(6)\left(\mathrm{UN}_{1} .565\right)$. Chemical analysis of the reaction products at 1000,1300 , and $1550 \mathrm{C}$ did not give a material balance. Vacuum-fusion analysis of the product of $\mathrm{UC}_{2}$ reacted at $1000 \mathrm{C}$ gave $6.27 \mathrm{w} / 0$ nitrogen and $1.72 \mathrm{w} / 0$ oxygen. This gave close balance, and indicated an oxygen contamination which caused an error in the chemical analysis for nitrogen. This oxygen is apparently in solid solution in the $\mathrm{U}_{2} \mathrm{~N}_{3}$ structure, for no uranium oxide phase could be detected. The closeness of total- and free-carbon values would indicate very little carbon combined in solid solution in the $\mathrm{U}_{2} \mathrm{~N}_{3}$ phases. All compositions were on the nitrogen-rich side of the binary tie line between $U_{2} N_{3}$ and $C$.

TABLE 5. ANALYSIS OF PRODUCTS OF URANIUM CARBIDE REACTIONS WITH NITROGEN AT 1 ATM

\begin{tabular}{|c|c|c|c|c|c|c|}
\hline \multirow{3}{*}{$\begin{array}{l}\text { Starting } \\
\text { Material }\end{array}$} & \multirow{3}{*}{$\begin{array}{c}\text { Temperature, } \\
\text { C }\end{array}$} & \multicolumn{4}{|c|}{ Composition, w/o } & \multirow[b]{3}{*}{$X \rightarrow$ Ray Phase Determination } \\
\hline & & & & Total & Free & \\
\hline & & $\mathrm{U}$ & $\mathrm{N}$ & C & C & \\
\hline UC & 1000 & 86.8 & 3.40 & 4.35 & 4.20 & $\mathrm{U}_{2} \mathrm{~N}_{3}$ \\
\hline $\mathrm{UC}_{2}$ & 1000 & 83.5 & 4.10 & 7.71 & 7.60 & $\mathrm{U}_{2} \mathrm{~N}_{3}$ \\
\hline UC & 1300 & 87.8 & 3.00 & 3.87 & 3.80 & $\mathrm{U}_{2} \mathrm{~N}_{3} \mathrm{a}_{\mathrm{O}}=10.658 \pm 0.005 \mathrm{~A}$ \\
\hline $\mathrm{UC}_{2}$ & 1300 & 84.5 & 2.70 & 7.36 & 7.30 & $\mathrm{U}_{2} \mathrm{~N}_{3}$ \\
\hline $\mathrm{UC}$ & 1550 & 87.3 & 6.60 & 4. 21 (a) & 3.80 & $\mathrm{U}_{2} \mathrm{~N}_{3} \mathrm{a}_{\mathrm{o}}=10.646 \pm 0.005 \mathrm{~A}$ \\
\hline $\mathrm{UC}_{2}$ & 1550 & 86.7 & 6.10 & $4.72^{(a)}$ & 4.30 & $\mathrm{U}_{2} \mathrm{~N}_{3}$ \\
\hline $\mathrm{UC}_{2}$ & 1800 & 87.7 & 4.60 & 7.70 & 2.20 & $\mathrm{U}(\mathrm{N}, \mathrm{C}) \mathrm{a}_{\mathrm{O}}=4.8923 \pm 0.0008 \mathrm{~A}$ \\
\hline $\mathrm{UC}_{2}$ & 2000 & 90.3 & 1.50 & 8.10 & 2.60 & $\begin{array}{l}U\left(C_{3} N\right) a_{0}=4.9416 \pm 0.0008 A+U_{2} \\
+C\end{array}$ \\
\hline
\end{tabular}

(a) The UC and $\mathrm{UC}_{2}$ powders reacted at $1550 \mathrm{C}$ were partially mixed during the heating.

Figures 11 and 12 show at $500 \mathrm{X}$ the microstructures of the solid UC2 samples reacted with nitrogen for $3 \mathrm{hr}$ at 1800 and $2000 \mathrm{C}$. The sample reacted at $1800 \mathrm{C}$ (Figure 11) contains a light-etching matrix phase composed of $U(N, C)$. The small darketching particles appear to be graphite, as does a slight amount of the material in the large cracks. The gray material in the cracks is mounting resin.

The $\mathrm{UC}_{2}$ specimen reacted with nitrogen at $2000 \mathrm{C}$ contains relatively coarse light-etching particles of $\mathrm{UC}_{2}$, as can be seen in Figure 12. Each particle contains a dark-etching material, probably $\mathrm{U}(\mathrm{C}, \mathrm{N})$, as a $\mathrm{rim}$ around the particles and also as thin bands within the light-etching particles. The black mottled areas between the lightetching particles are graphite. The gray mounting resin fills some void areas in the graphite. 


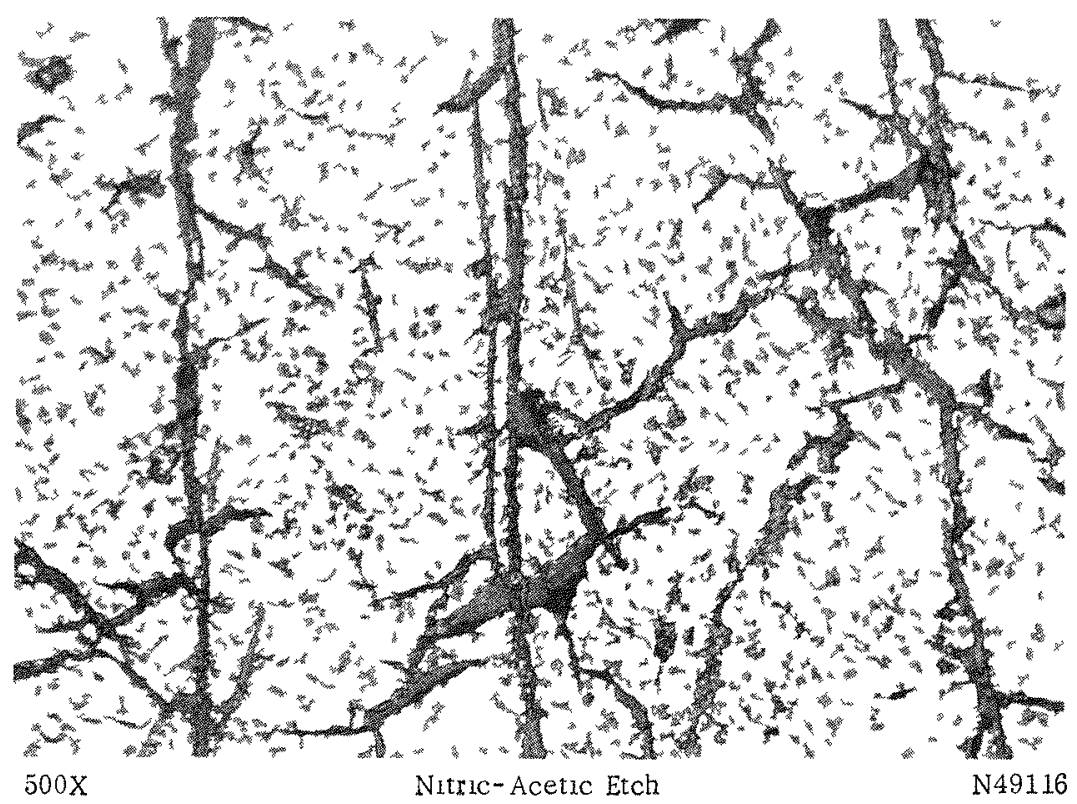

Showa light-etching $\mathrm{U}(\mathrm{N} \mathrm{C})$ inatrıx with small dark-etching graphite partıcles, Coarce dark gray material in cracks is mounting rein.

FIGURE 11. UC 2 REACTED WITH DRY NITROGLN AT 1800 C FOR 3 HR AND SLOWLY COOLED IN NITROGEN

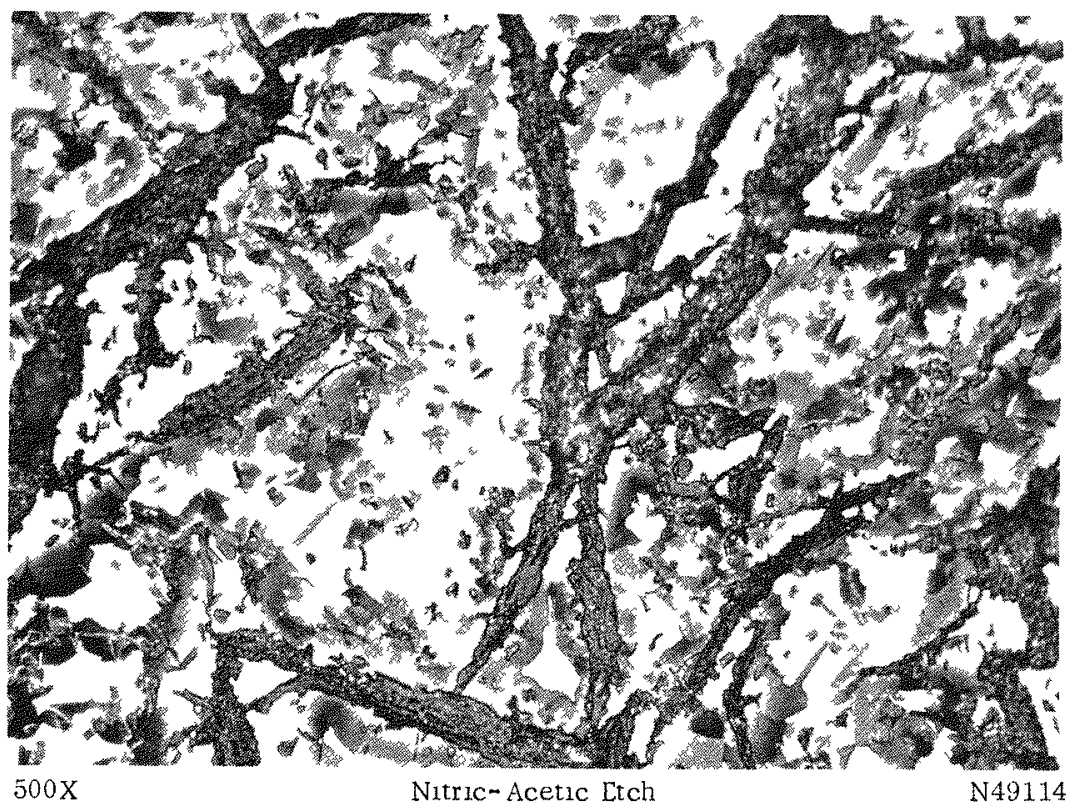

Shows light-etching metallic $\mathrm{UC}_{2}$ containing thin bands of $U(C, N)$. Coarse mottled dark gray-to-black bands are graphite.

FIGURE 12. UC $\mathrm{UC}_{2}$ REACTED WITH DRY NITROGLN AT 2000 C FOR 3 HR AND SLOWLY COOLED IN NITROGEN A TMOSPHERL 
The $\mathrm{X}$-ray diffraction data for the solid $\mathrm{UC}_{2}$ specimens reacted with nitrogen at 1800 and $2000 \mathrm{C}$ agreed with those reported in Table 5 for powder compacts used in the same experiments. The $U_{2}$ reacted with nitrogen at $1800 \mathrm{C}$ contained $U(N, C)+g r a p h-$ ite and was located in the $U(N, C)+C$ field on the diagram (Figure 1$)$. This $U(N, C)$ solid solution contains $0.95 \mathrm{~mol}$ fraction of UN according to the unit-cell parameter. The absence of appreciable amounts of the $\mathrm{UC}_{2}$ phase indicates that the amount of combined carbon should be low, about $0.5 \mathrm{w} / \mathrm{o}$. The difference in chemical analysis between total and free carbon is normally assumed to be combined carbon. However, the free carbon is obtained from the residue after an oxidizing dissolution of the uranium phase, and the finely divided graphite shown in the photomicrograph (Figure 11) could be oxidized during this treatment. Therefore, the analysis for combined carbon is considered not reliable for this sample.

The relative stability under 1 atm of nitrogen of uranium nitride and uranium carbide shifts between 1800 and $2000 \mathrm{C}$. At $1800 \mathrm{C}$, the nitride phase is more stable than the carbide. At $2000 \mathrm{C}$, the carbide phase is more stable, $\mathrm{UC}_{2}$ existing with $\mathrm{U}(\mathrm{C}, \mathrm{N})$ and graphite. The $\mathrm{U}(\mathrm{C}, \mathrm{N})$ phase in the $\mathrm{UC}_{2}$, reacted at $2000 \mathrm{C}$ with nitrogen, had a unit-cell. parameter essentially the same as for $U(C, N)$ phase in the three-phase sample at $1800 \mathrm{C}$ under argon. This indicates that the mol fraction of $U C$ in $U(C, N)$ is about 0.62 . From the estimates of the heat of formation(7), the free-energy change was calculated for the reaction $\mathrm{UC}_{2}+1 / 2 \mathrm{~N}_{2} \rightarrow \mathrm{UN}+2 \mathrm{C}$. At $1800 \mathrm{C}$ the $\Delta \mathrm{F}$ was $+1.6 \mathrm{kcal}$ per $\mathrm{g}$ mol and at $2000 \mathrm{C}$ it was $+6 \mathrm{kcal}$ per $\mathrm{g}$ mol. The experimental observations indicated the reaction was almost complete at $1800 \mathrm{C}$. This would indicate some error in the estimated free energy at $1800 \mathrm{C}$, which could be in the heat of formation, $\Delta \mathrm{H}$, or in the assumption that $\Delta \mathrm{C}_{\mathrm{p}}=0$. The free energy of the $\mathrm{U}(\mathrm{N}, \mathrm{C})$ solid solution would be somewhat different from that of UN. With decreased nitrogen pressure the carbides would become more stable as observed for reaction in argon or vacuum. It is estimated that at $2000 \mathrm{C} 3.8$ atm of nitrogen would be needed to form UN from $\mathrm{UC}_{2}$.

Formation of $\mathrm{U}_{2} \mathrm{C}_{3}$

To determine the possibility of nitrogen solubility in $\mathrm{U}_{2} \mathrm{C}_{3}$, attempts were made to form $\mathrm{U}_{2} \mathrm{C}_{3}$ by reaction of compressed powders of $\mathrm{UN}, \mathrm{UC}$, and $\mathrm{UC}_{2}$ at 1650 to $1700 \mathrm{C}$. The reaction between $\mathrm{UC}$ and $\mathrm{UC}_{2}$ was checked in the same experiment as a control. Very little $\mathrm{U}_{2} \mathrm{C}_{3}$ was formed. Phase analyses are given in Table 6. Specimen 16, composed of $U C, U N$, and $U C_{2}$, formed $U(C, N)$. Uranium sesquicarbide, $U_{2} C_{3}$, was made by arc melting an alloy containing $7.03 \mathrm{w} / 0$ carbon and then heat treating pieces of the ingot at $1650 \mathrm{C}$ for about $2 \mathrm{hr}$. The product of this treatment was $\mathrm{U}_{2} \mathrm{C}_{3}$ plus $\mathrm{UC}_{2}$, with the composition $92.5 \mathrm{w} / 0$ uranium $-7.51 \mathrm{w} / 0$ carbon $-0.008 \mathrm{w} / 0$ nitrogen. This material was crushed to minus $325 \mathrm{mesh}$, mixed with UN, and heated at 1650 to $1700 \mathrm{C}$ for $4 \mathrm{hr}$ in vacuum. The resulting product, Specimen 27, was essentially all $\mathrm{U}_{2} \mathrm{C}_{3}$ with the composition $92.8 \mathrm{w} / 0$ uranium $-7.00 \mathrm{w} / 0$ carbon $-0.001 \mathrm{w} / 0$ nitrogen. The analysis showed practically no nitrogen, and the $\mathrm{U}_{2} \mathrm{C}_{3}$ unit-cell parameter given in Table 6 was the same as in the starting material. Calculation of the mols of carbon and nitrogen relative to uranium before and after firing indicated a loss of both carbon and nitrogen. The UN evidently reacted with the $\mathrm{UC}_{2}$ to form $\mathrm{U}_{2} \mathrm{C}_{3}$ and to evolve nitrogen and $\mathrm{CN}$. This result, together with the finding of $U(C, N)$ in Specimen 16, indicates very little solubility of nitrogen in $\mathrm{U}_{2} \mathrm{C}_{3}$. 
TABLE 6. PHASES OF $\mathrm{U}_{2} \mathrm{C}_{3}$ REACTIONS AT 1650 TO $1700 \mathrm{C}$

\begin{tabular}{|c|c|c|c|}
\hline \multirow[b]{2}{*}{ Specimen } & \multirow[b]{2}{*}{ Initial Phases } & \multicolumn{2}{|c|}{$\begin{array}{l}\text { Product Phases Identified After Reaction at } \\
\qquad 1700 \mathrm{C} \text { in Vacuum }\end{array}$} \\
\hline & & By Metallography & By X-Ray Diffraction \\
\hline $15 \mathrm{~A}$ & $\mathrm{UC}_{2}+\mathrm{U}(\mathrm{C}, \mathrm{N})$ & $\mathrm{UC}_{2}+\mathrm{U}(\mathrm{C}, \mathrm{N})$ & $\mathrm{UC}_{2}+\mathrm{U}(\mathrm{C}, \mathrm{N})$ \\
\hline 16 & $U N+U C+U_{2}$ & $\mathrm{UC}_{2}+\mathrm{U}(\mathrm{C}, \mathrm{N})+\operatorname{trace} \mathrm{U}_{2} \mathrm{C}_{3}$ & $\begin{array}{l}\mathrm{UC}_{2}+\mathrm{U}(\mathrm{C}, \mathrm{N}) \text { with } \mathrm{a}_{\mathrm{O}}=4.9497 \\
\pm 0.0005 \mathrm{~A}\end{array}$ \\
\hline 17 & $\mathrm{UC}_{2}+\mathrm{UC}$ & $\mathrm{UC}_{2}+\mathrm{UC}+\operatorname{trace} \mathrm{U}_{2} \mathrm{C}_{3}$ & $\begin{array}{l}\mathrm{UC}_{2}+\mathrm{UC} \text { with } \mathrm{a}_{\mathrm{O}}=4.9564 \pm \\
0.0005 \mathrm{~A}\end{array}$ \\
\hline 27 & $\mathrm{UC}_{2}+\mathrm{U}_{2} \mathrm{C}_{3}$ with $\mathrm{a}_{\mathrm{O}}=8.0885 \pm 0.0005 \mathrm{~A}$ & $\mathrm{U}_{2} \mathrm{C}_{3}$ & $U_{2} C_{3}$ with $a_{0}=8.0892 \pm 0.0005 \mathrm{~A}$ \\
\hline
\end{tabular}

TABLE 7. RELATIVE LOSS OF CARBON AND NITROGEN FOR REACTIONS IN URANIUM-NITROGEN-CARBON SYSTEM AT 1800 C IN ARGON

\begin{tabular}{|c|c|c|c|c|c|c|c|}
\hline \multirow[b]{3}{*}{ Specimen } & \multirow[b]{3}{*}{ Reactants } & \multicolumn{6}{|c|}{ Atomic Ratio } \\
\hline & & \multicolumn{2}{|c|}{ Initial } & \multicolumn{2}{|c|}{ Final } & \multicolumn{2}{|c|}{ Loss } \\
\hline & & $\mathrm{C} / \mathrm{U}$ & $\mathrm{N} / \mathrm{U}$ & $\mathrm{C} / \mathrm{U}$ & $\mathrm{N} / \mathrm{U}$ & $\Delta \mathrm{C} / \mathrm{U}$ & $\Delta N / U$ \\
\hline 3 & $\mathrm{UC}+\mathrm{U}_{2} \mathrm{~N}_{3}$ & 0.48 & 0.81 & 0.33 & 0.63 & 0.15 & 0.18 \\
\hline 4 & $\mathrm{UC}_{2}+\mathrm{U}_{2} \mathrm{~N}_{3}$ & 0.90 & 0.82 & 0.72 & 0.27 & 0.18 & 0.55 \\
\hline 9 & $U N+U_{2}$ & 0.90 & 0.51 & 0.78 & 0.24 & 0.12 & 0.27 \\
\hline 10 & $\mathrm{UN}+\mathrm{C}$ & 1.00 & 1.00 & 0.94 & 0.28 & 0.06 & 0.72 \\
\hline 11 & $U N+U C$ & 0.30 & 0.70 & 0.24 & 0.68 & 0.06 & 0.02 \\
\hline 12 & $\mathrm{UN}+\mathrm{C}$ & 2.00 & 0.96 & 1.85 & 0.38 & 0.15 & 0.58 \\
\hline 13 & $\mathrm{UC}+\mathrm{U}_{2} \mathrm{~N}_{3}$ & 0.33 & 1.08 & 0.28 & 0.67 & 0.05 & 0.41 \\
\hline 14 & $\mathrm{UC}+\mathrm{U}_{2} \mathrm{~N}_{3}$ & 0.81 & 0.26 & 0.74 & 0.27 & 0.07 & 0.01 \\
\hline 15 & $\mathrm{U}_{2} \mathrm{~N}_{3}+\mathrm{UC}_{2}$ & 1.55 & 0.25 & 1.51 & 0.08 & 0.04 & 0.17 \\
\hline 25 & $U N+U_{2}+C$ & 2.38 & 0.20 & 2.22 & 0.02 & 0.16 & 0.18 \\
\hline 26 & $\mathrm{UN}+\mathrm{UC}_{2}$ & 0.78 & 0.19 & 0.75 & 0.25 & 0.03 & $0.0 x^{(a)}$ \\
\hline 27 & $\mathrm{UN}+\mathrm{U}_{2} \mathrm{C}_{3}+\mathrm{UC}_{2}$ & 1.53 & 0.05 & 1.49 & 0 & 0.04 & 0.05 \\
\hline
\end{tabular}

(a) Weight gain. 
The compositions for the ternary-diagram section at $1800 \mathrm{C}$ in argon (Figure 1) were made by reacting mixtures of $\mathrm{UN}, \mathrm{U}_{2} \mathrm{~N}_{3}, \mathrm{UC}, \mathrm{UC}_{2}$, and $\mathrm{C}$. The reactions can be grouped as follows:

$$
\begin{aligned}
& \text { (1) } \mathrm{UN}+\mathrm{UC} \rightarrow \mathrm{U}(\mathrm{C}, \mathrm{N}) \\
& \text { (2) } \mathrm{UN}+\mathrm{UC}_{2} \rightarrow \mathrm{U}(\mathrm{C}, \mathrm{N})+\mathrm{N}_{2}+\mathrm{CN} \\
& \text { (3) } \mathrm{U}_{2} \mathrm{~N}_{3}+\mathrm{UC} \rightarrow \mathrm{U}(\mathrm{C}, \mathrm{N})+\mathrm{N}_{2}+\mathrm{CN} \\
& \text { (4) } \mathrm{U}_{2} \mathrm{~N}_{3}+\mathrm{UC}_{2} \rightarrow \mathrm{U}(\mathrm{C}, \mathrm{N})+\mathrm{N}_{2}+\mathrm{CN} \\
& \text { (5) } \mathrm{UN}+\mathrm{C} \rightarrow \mathrm{U}(\mathrm{C}, \mathrm{N})+\mathrm{UC}_{2}+\mathrm{N}_{2}+\mathrm{CN}
\end{aligned}
$$

The equations are not balanced because proportions of the products depend upon the initial proportions of the reactants chosen for a given experiment. The formation of $\mathrm{CN}$ is inferred from the loss of nitrogen and carbon from the preparations during reaction, as shown in Table 7. This table gives the atomic ratios of carbon and nitrogen to uranium before and after reaction. The molecule of CN presumably decomposes at 1 atm of nitrogen since there was no appreciable loss of carbon in the reactions with nitrogen gas.

The only solid-solution field found at $1800 \mathrm{C}$ for the uranium-nitrogen-carbon system is between UN and UC with a slight excess of carbon and nitrogen. Since at temperatures above $2200 \mathrm{C}$ the UC and the high-temperature cubic phase of $\mathrm{UC}_{2}$ form solid solutions $(2,8)$, one would expect continuous solid solution for the ternary field UC-UC $2^{-}$ UN. The composition of this solid solution would depend upon the nitrogen pressure. However, at lower temperatures such a solid solution should dissociate into $\mathrm{U}(\mathrm{C}, \mathrm{N})+$ $\mathrm{UC}_{2}$ and/or $\mathrm{C}$ and at a sufficiently high nitrogen pressure to $\mathrm{U}_{2} \mathrm{~N}_{3}+\mathrm{C}$.

Since the composition of $\mathrm{U}_{2} \mathrm{~N}_{3}$ increases to $\mathrm{UN}_{2}$ with increasing nitrogen pressure(1) $(126 \mathrm{~atm})$ the same variation in equilibrium with carbon is expected. UN 2 has the fluorite structure(1) similar to the high-temperature form of $\mathrm{UC}_{2}$. Therefore, at high temperatures, above $2200 \mathrm{C}$, and at high nitrogen pressures, the solid-solution field may be between $\mathrm{UN}_{2}$ and $\dot{U}_{2}$. However, no experimental proof for this hypothesis has been obtained in this study.

The lack of solid solubility of nitrogen in $\mathrm{UC}_{2}$ and $\mathrm{U}_{2} \mathrm{C}_{3}$ would indicate that single carbon bonds do not exist in the se compounds, but rather double to triple bonds. Concurrent neutron-diffraction-structure studies $(9)$ have determined that there are carbon double bonds in $\mathrm{UC}_{2}$ and also in $\mathrm{U}_{2} \mathrm{C}_{3}$.

\section{ACKNOWLEDGMENT}

The chemical analyses were done by F. E. Huber, Jr. The authors appreciate discussions with M. W. Mallett and C. M. Schwartz. 


\section{REFERENCES}

(1) Rundle, R. F., Baenziger, N. C., Wilson, P. D., and McDonald, R. A., "The Structure of the Carbides, Nitrides, and Oxides of Uranium", J. Am. Chem. Soc., $70,99(1948)$.

(2) Wilson, W. B., private communication.

(3) Mallett, M. W., and Gerds, A. F., "Reaction of Nitrogen With Uranium", J. Electro. Chem. Soc., 102, 292 (1955).

(4) Steyermark, A., Quantitative Organic Microanalysis, Blakeston Company, Philadelphia (1951).

(5) Vaughan, D. A., Melton, C. W., and Gerds, A. F., "Experiments on the Preparation of $\mathrm{UO}_{2-\mathrm{x}}$ and UO", BMI-1175 (March 6, 1957).

(6) Mallett, M. W., private communication.

(7) Rossini, F. D., Wagman, D. D., Evans, W. H., Levine, S., and Jaffee, I., "Selected Values of Chemical Thermodynamic Properties", Nat. Bur. Stds. Circ. 500 (February 1, 1952).

(8) Mallett, M. W., Gerds, A. F., and Nelson, H. R., "The Uranium-Carbon System", AECD-3226 (April 1, 1951).

(9) Austin, A. E., "Neutron Diffraction Studies of Uranium Carbides", to be published. 